\title{
Conservation of Scops Owl Otus scops in the Alps: relationships with grassland management, predation risk and wider biodiversity
}

\author{
FABRIZIO SERGIO, ${ }^{1 *}$ LUIGI MARCHESI $^{2}$ \& PAOLO PEDRINI ${ }^{2}$ \\ ${ }^{1}$ Department of Conservation Biology, Estación Biológica de Doñana, C.S.I.C., Avda. de María Luisa s/n., \\ Pabellón del Perú, Apdo 1056, 41013 Seville, Spain \\ ${ }^{2}$ Raptor Conservation Research Unit, Trento Museum of Natural Sciences, via Calepina 14, 38100 Trento, Italy
}

\begin{abstract}
The Scops Owl Otus scops is the most endangered and least studied owl in Europe, with widespread declines reported throughout Europe. The species is qualitatively associated with two threats: changes in agricultural practices and predation by Tawny Owls Strix aluco. We investigated these two threats to a population in the Alps, where land abandonment is causing widespread woodland expansion with unknown consequences. Predation risk and environmental indicators of the degree of agricultural change both predicted Scops Owl distribution. Furthermore, agricultural change also affected broader biodiversity, as estimated by the richness and diversity of bird and diurnal butterfly species. This resulted in a strong association between Scops Owl presence and wider biodiversity, which held at different spatial scales and justified a conservation focus on a single, threatened species. The persistence of Scops Owls in the Alps could be promoted through subsidies halting land abandonment and promoting extensive grassland management practices. Such interventions would have the additional advantage of yielding broader biodiversity benefits.
\end{abstract}

Keywords: agricultural change, butterflies, indicator species, intraguild predation, Alpine meadows.

In most European mountain systems, the declining profitability of agro-pastoral activities is causing widespread land abandonment, with consequent woodland expansion into previously cultivated areas (Cernusca et al. 1999) and negative impacts on species of open habitats (Tucker \& Evans 1997, Laiolo et al. 2004). In the Alps, woodland area is increasing through natural regeneration by $0.5-1 \%$ per year, almost exclusively at the expense of low intensity pastures (Barbaro et al. 2001, CIPRA 2001, Dirnböck et al. 2003), one of the most threatened habitats of Europe (Niemelä \& Baur 1998, Canals \& Sebastià 2000 and references therein). In particular, most of this increase occurs at low to medium elevations, where land abandonment causes the loss of grassland fields originally managed for fodder production in association with the once flourishing livestock industry, an agro-pastoral system which dates back 6000 years (Lichtenbergen 1994, Dirnböck et al. 2003).

*Corresponding author.

Email: fsergio@ebd.csic.es
This promotes a temporary increase in shrub vegetation, which ultimately develops into woodland, leading to long-term loss of alpine grassland and pastures and declines in landscape heterogeneity. Such large-scale changes require assessment of their potential impact on conservation-sensitive species typical of open habitats, such as the threatened Scops Owl Otus scops.

The Scops Owl is a small nocturnal raptor typical of open and semi-open grassland habitats of the middlelower latitudes of the Palaearctic (Cramp 1985). Its European populations are declining steeply, making it the most threatened owl in Europe (Arlettaz et al. 1991, Bavoux et al. 1997). In Europe, the species is currently classified as SPEC 2 with depleted populations (i.e. concentrated in Europe, with an unfavourable conservation status and demonstrated declines; Burfield \& van Bommel 2004). Furthermore, the Scops Owl is probably the least studied owl in Europe (Marchesi \& Sergio 2005), which makes conservation plans and assessments even more difficult. Among the few studies conducted so far, there is a consensus that two factors are driving these declines 
(Marchesi \& Sergio 2005): changes in agricultural practices, which may have depressed habitat and prey availability, and predation by Tawny Owls Strix aluco, which often occur sympatrically with Scops Owls (Mikkola 1983, Galeotti \& Gariboldi 1994). However, these are untested hypotheses because no quantitative analysis has confirmed their relative importance.

In the Alps, Scops Owls were common in all grassland habitats of medium-low elevation at the beginning of the 1900s (Arlettaz 1990, Arlettaz et al. 1991, Marchesi \& Sergio 2005). Most of this grassland was artificially maintained and originally extensively managed for fodder production (Lichtenbergen 1994, Dirnböck et al. 2003). Subsequently, valley floors and lower slopes were converted to intensive agriculture (such as vineyards) and mediumelevation grasslands were either more intensively managed (with higher inputs of fertilizers, higher frequency of harvest, progressive hedgerow removal), or abandoned because they were unprofitable (CIPRA 2001, Fusco 2002). The latter process is still causing large-scale erosion of open habitats through scrub encroachment throughout the Alps (Pedrini \& Sergio 2002, Laiolo et al. 2004). As a result, the Scops Owl is now virtually absent from low-elevation areas and concentrated around remnants of mediumelevation grassland areas. There, the species feeds mainly on grasshoppers (Orthoptera), other large invertebrates, small birds and small mammals (Arlettaz et al. 1991, Marchesi \& Sergio 2005).

Previous studies have suggested that, in the Alps, the species may be affected by the same two threats identified at the continental level, namely agricultural change and predation by Tawny Owls (Arlettaz et al. 1991, Galeotti \& Gariboldi 1994, Marchesi \& Sergio 2005). In particular, Arlettaz et al. (1991) have suggested that the features of agricultural intensification that may negatively affect Scops Owls (e.g. larger field size, lower hedgerow availability, removal of old trees, etc.) are the same as those that cause declines in broader biodiversity levels associated with the grassland habitats of the Alps. This is important because it suggests that Scops Owls may function as sentinels of biodiversity value (Sergio et al. 2005a, 2006a) and it links Scops Owl declines with parallel biodiversity declines and with the homogenization of the alpine landscape. A study on this species may therefore have broader value for the conservation management of the whole alpine landscape.

Here, we assess whether the twin threats of predation by Tawny Owls and agricultural change explain the current distribution and past pattern of extinction of the species in the central-eastern Italian Alps by comparing sites occupied or not by the owl across a gradient of agricultural intensification and predation risk by Tawny Owls. We further explore the association between Scops Owl distribution and wider biodiversity value at various spatial scales.

\section{METHODS}

\section{Study areas}

Scops Owls were surveyed in 2002 and 2003 in two $50 \mathrm{~km}^{2}$ study plots located on the slopes of the Vallarsa valley $\left(45^{\circ} 47^{\prime} \mathrm{N}, 11^{\circ} 07^{\prime} \mathrm{E}\right)$ and of Mount Baldo $\left(45^{\circ} 49^{\prime} \mathrm{N}, 11^{\circ} 57^{\prime} \mathrm{E}\right)$, both located in the centraleastern Italian pre-Alps. The two plots were $21 \mathrm{~km}$ apart and separated by a stretch of the intensively cultivated lowland of the River Adige, where Scops Owls do not occur. The two sites were chosen because they vary greatly in the degree of agricultural change and in their densities of Tawny Owls.

In the Vallarsa plot, elevation ranged from 220 to $1460 \mathrm{~m}$. The landscape was characterized by steep slopes covered by deciduous woodland, interspersed with extensive cultivations dominated by grassland fields, usually located around each of 38 small villages. Many of the grassland fields were abandoned and subject to scrub encroachment; the rest were mowed only once a year, in contrast to the two or more times a year typical of the more intensive management elsewhere in the region. The Vallarsa area could be considered a snapshot of the traditional, rural Alpine landscape at the beginning of the 20th century.

The Baldo plot was chosen as a control plot where the species was known to be present in historical times (Bonomi 1884). Elevation (range: $210-1400 \mathrm{~m}$ ), relief, aspect and land-uses were similar to the Vallarsa area and grassland fields were abundant, but managed more intensively (with larger field size, lower availability of network habitats, and mowed at least twice a year). Therefore, the Vallarsa-Baldo comparison represented a spatial equivalent of the temporal gradient of agricultural intensification. Furthermore, Tawny Owls were more abundant in the Baldo plot (60 territories per $100 \mathrm{~km}^{2}$ ) than in the Vallarsa area (23 territories per $100 \mathrm{~km}^{2}$; Marchesi et al. 2006). Finally, previous surveys suggested that Scops Owls were abundant in Vallarsa but absent from the Baldo area despite the high availability of apparently suitable habitats (e.g. grassland fields). Therefore, the two sites were chosen to investigate the factors associated 

with the recent disappearance of the species from some areas but not others. Ideally, sampling a larger number of study areas would have provided a stronger test of the hypothesis. However, manpower limitations and the large amount of fieldwork required to gather the biodiversity estimates prevented this.

\section{Data collection}

Scops Owl territories were censused by passive auditory surveys and by acoustic-lure surveys (details in Marchesi \& Sergio 2005). A territory was defined as an area where one or more nests were found in different years but where only one pair nested within any one year. Each year the calls of the territorial owls were recorded to record the identity of each territoryholder through spectrogram analysis (Galeotti \& Sacchi 2001) and so to avoid pseudoreplication of the same individual across years in any analysis.

We used the species richness and diversity of birds and butterflies (Rhopalocera) as surrogates of wider biodiversity. These two taxa are commonly used for biodiversity assessment because of their visibility, ease of census and positive relationships with the diversity of other taxa (ICBP 1987, 1992, Gaston 1996, Kerr et al. 2000). We censused birds by song recognition during point counts and butterflies by capturing all those sighted within a rectilinear 20-m transect. The transect was plotted in the grassland field nearest to the sample location (Scops Owl nest or random location, see below) and was always more than $20 \mathrm{~m}$ from the field edge (so as to minimize edge effects). All butterflies were identified to species level according to Chemini (1993) and Tolman (1997), except for species of the genera Plebejus and Thymelicus (only identified to genus level). The location of Tawny Owl territories was already known as part of a parallel study on this species (Marchesi et al. 2006, Sergio et al. 2007).

\section{Statistical analysis}

To investigate the factors potentially affecting Scops Owl distribution within and between the two sites, we measured a number of environmental and biodiversity variables (Table 1) at 40 Scops Owl territories, 40 locations randomly located within the Vallarsa plot and 40 locations randomly located within the Baldo plot. The 40 owl territories were all those occupied at least once during the 2 years of study in the Vallarsa area. When two different nests were used within the same territory in subsequent years, we randomly selected one of them for the analyses. All random locations were generated by means of the extension 'Animal Movement' of the GIS software ArcView 3.2 (Hooge \& Eichenlaub 1997). To ensure that they were adequate controls, random locations were constrained to fall in the immediate neighbourhood of grassland patches (no Scops Owl nests were far away from grassland), over cavities judged as potentially suitable for Scops Owls, and on buildings and trees in the same proportion as that observed for real Scops Owl nests (Marchesi \& Sergio 2005). The variables listed in Table 1 were measured in the field or by digitizing 1-m resolution aerial colour photographs and were chosen so as to measure general topography, landscape structure and composition at various spatial scales; the availability of potential nesting and foraging habitats (e.g. grassland), the distance to the territories of Tawny Owls, habitat diversity, and wider biodiversity. The interspersion indexes and the variables related to field size and shape, frequency of mowing, length of hedgerows, length of stone-walls and number of isolated Walnut Juglans regia trees were included as potential indicators of the degree of agricultural change (e.g. Andrews \& Rebane 1994, Brouer \& Crabtree 1999).

A reliable estimate of wider biodiversity should reflect the multivariate nature of biodiversity and incorporate estimates of richness, evenness and vulnerability of the sampled species (e.g. Gaston 1996, Purvis \& Hector 2000). A European vulnerability score was available only for bird species, which are classified as Species of European Conservation Concern (SPEC) categories 1, 2, 3, 4 and non-SPEC, in order of decreasing vulnerability (Tucker \& Heath 1994). Therefore, to provide a multivariate measure of biodiversity incorporating the above three components, we carried out a principal component analysis (PCA, Tabachnick \& Fidell 1996) using the following variables: (1) the richness of butterflies, (2) the richness of all bird species, (3) the richness of bird species in categories SPEC $1+2+3+4$, (4) the richness of bird species in categories SPEC $1+2+3$ (richness of SPEC 1 and $1+2$ were not used as they involved too many zero counts), and (5-8) the diversity of each of the above species groups, estimated by means of the Shannon diversity index (Krebs 1998). The first axis of this PCA, hereafter referred to as 'biodiversity index', explained $70 \%$ of the sample variance and had high positive loadings for all these variables (all $r \geq 0.74$ ). Therefore, higher values of the index indicate higher biodiversity. 
Table 1. Environmental variables, indicators of agricultural intensification and biodiversity estimates measured at Scops Owl nests and random sites (Italian Alps, 2002-03).

\begin{tabular}{|c|c|}
\hline Variable & Description \\
\hline \multicolumn{2}{|l|}{ Topography } \\
\hline Elevation $(\mathrm{m})$ & Elevation asl \\
\hline Aspect & Factor variable: 1 = northern orientation, 2 = southern orientation* \\
\hline$\%$ Slope & $\%$ slope within $100 \mathrm{~m}$ of the nest \\
\hline Ruggedness index & No. of contour lines crossed by two N-S and W-E transects of $200 \mathrm{~m}$ \\
\hline \multicolumn{2}{|l|}{ Distance variables } \\
\hline Nearest neighbour distance (NND) (m) & Distance to the nearest Scops Owl territory or random location† \\
\hline Distance to Tawny Owl (m) & Distance to the nearest Tawny Owl territory \\
\hline Distance to grassland (m) & Distance to the nearest grassland field \\
\hline Distance to building (m) & Distance to the nearest building \\
\hline \multicolumn{2}{|l|}{ Landscape-level } \\
\hline$\%$ managed grassland $\ddagger$ & $\%$ extent of managed grassland within a $290-\mathrm{m}$ radius \\
\hline$\%$ grassland + shrubs $\ddagger$ & $\%$ extent of abandoned grassland + shrub-encroachment within $290 \mathrm{~m}$ \\
\hline$\%$ grassland $\ddagger$ & $\%$ extent of managed and abandoned grassland within 290 m \\
\hline$\%$ intensive farmland $\ddagger$ & $\%$ extent of intensively managed vineyards and apple groves within $290 \mathrm{~m}$ \\
\hline$\%$ woodland $\ddagger$ & $\%$ extent of woodland within $290 \mathrm{~m}$ \\
\hline$\%$ urban areas & $\%$ extent of urban areas within $1.7 \mathrm{~km}$ of the nest \\
\hline$\%$ water & $\%$ extent of water bodies \\
\hline No. of houses $\ddagger$ & No. of buildings within $290 \mathrm{~m}$ \\
\hline Habitat richness§ł & No. of habitat types within $290 \mathrm{~m}$ \\
\hline Habitat diversity§ & Shannon index of habitat diversity (see Methods, Krebs 1998) \\
\hline Interspersion index§ & No. of habitat boundaries crossed by two N-S and W-E transects \\
\hline Grassland interspersion§ & No. of boundaries between grassland and other habitats crossed by two N-S and W-E transects \\
\hline Hedgerow interspersion§ & No. of boundaries between grassland and hedgerows crossed by two N-S and W-E transects \\
\hline Hedgerows $(\mathrm{m}) \S \ddagger$ & Length of hedgerows within $290 \mathrm{~m}$ \\
\hline \multicolumn{2}{|l|}{ Grassland field-level } \\
\hline Field size $\left(m^{2}\right) \S$ & Area of the field \\
\hline Field perimeter $(\mathrm{m}) \S$ & Perimeter of the field \\
\hline Perimeter/area§̧ & Perimeter of the field divided by its area \\
\hline Walnut trees§ & No. of Walnut trees within the field and along its perimeter \\
\hline Stone walls $(\mathrm{m}) \S$ & Length of stone walls within the field and along its perimeter \\
\hline Mowing frequency§ & $1=$ grassland mown once a year; 2 = mown twice a year $\mathbb{T}$ \\
\hline \multicolumn{2}{|l|}{ Biodiversity } \\
\hline Biodiversity index & $\begin{array}{l}\text { First factor of a principal component analysis on richness, diversity and vulnerability of bird } \\
\text { and butterfly species (see Methods) }\end{array}$ \\
\hline
\end{tabular}

*Converted to a categorical variable, so as to be able to fit it to multivariate models.

†Distance of each owl territory to the nearest territory and of each random location to the nearest random location.

łEqual to half the mean NND of the local Scops Owl population (Marchesi \& Sergio 2005).

$\S$ Variables used as indicators of the intensification of agricultural practices: apart from field size and mowing frequency, they increase with increasingly extensive farming practices.

IThis also applies to all the grassland fields within $290 \mathrm{~m}$ of the nest or random location.

To gain an understanding of the correlates of biodiversity value in our study system, we related biodiversity to environmental variables and indicators of agricultural intensity by means of multiple regression (Sokal \& Rohlf 1981).

Logistic regression (Tabachnick \& Fidell 1996) was used to analyse the factors discriminating between 40 Scops Owl territories (all of them in the Vallarsa area), 40 locations randomly plotted in the Baldo area and 40 locations randomly plotted within the
Vallarsa area. Because Scops Owls are now virtually extinct in the Baldo plot, the first comparison investigates the factors which may have driven the past population decline, while the second highlights the factors selected or avoided by the species within a large area that is still occupied. To further investigate the potential direct link between Scops Owls and biodiversity, the logistic regressions were run twice, with and without the biodiversity index as an explanatory variable. 
Finally, to test the relationship between biodiversity and Scops Owl distribution and abundance at a larger spatial scale, we used atlas data on the richness of bird, amphibian and reptile species in a grid of $10 \times 10 \mathrm{~km}$ quadrats covering the whole Trento region $\left(6200 \mathrm{~km}^{2}\right)$ (Sergio \& Pedrini 2007). We further calculated the richness of bird species in SPEC categories $1+2+3+4$ and $1+2+3$. We then compared these biodiversity estimates between 21 quadrats occupied by Scops Owl and 21 random quadrats not occupied by the species, and correlated the biodiversity estimates with the number of Scops Owl territories recorded in each of the 21 occupied quadrats.

In all analyses, logistic and multiple regression models were run through a standard and a generalized linear model procedure (GLM, software GLIM 4); the model with the highest predictive power was retained. GLM modelling procedures followed Crawley (1993): all explanatory variables were fitted to the model, removed one at a time from the maximal model and the associated change in model deviance assessed by an F-test for least squares regression (GLM model with normal errors and an identity link function) or a Chi-squared test for logistic regression (GLM model with binomial errors and a logit link function). To reduce collinearity and the number of variables fitted to multivariate models, we used the method of variable reduction proposed by Green (1979) and commonly employed in habitat selection studies (e.g. Sergio et al. 2005b and references therein). In this method, pairs of strongly intercorrelated variables $(r>0.6)$ are considered as estimates of one underlying factor. Only one of the two was retained for analysis, usually the one perceived as more important by the study organism. Of the remaining variables, only those for which significant univariate differences $(P<0.1)$ were detected among nests and random locations were included in multivariate analyses. Because the Tawny Owl is an essentially woodland species and the Scops Owl a grassland specialist, they may appear to avoid each other because of different habitat associations. To control for such bias, we fitted to the models the percentage of woodland, Walnut trees and their interaction regardless of whether they had been retained through the variable reduction method.

In all analyses, each owl territory was used only once to avoid pseudoreplication, means are given \pm 1 se, tests are two-tailed, and statistical significance was set at $\alpha \leq 0.05$. Sequential Bonferroni corrections were performed on multiple statistical tests when appropriate.

\section{RESULTS}

The indicators of intensification of agricultural practices differed significantly between the areas around the 40 Scops Owl territories, the Baldo random locations and the random locations in the Vallarsa area (Table 2 \& Fig. 1). Indices of wider biodiversity varied in parallel, being highest in owl territories, lowest in the Baldo plot and intermediate at the random locations in Vallarsa (Table 2, Fig. 2). Indices of wider biodiversity declined with increasing mowing frequency and increased with habitat richness, the availability of hedgerows and the abundance of Walnut trees (Table 3).

\section{Predictors of Scops Owl occurrence}

In the 2 years of research, 40 territories were occupied in at least 1 of the 2 years in the Vallarsa area and only one territory in the Baldo area. The latter territory was known to be unoccupied in previous years and it disappeared between the first and second years of the study.

When comparing the 40 territories of the Vallarsa study area with the 40 locations randomly plotted within Mount Baldo, Scops Owl territories were further from Tawny Owls and had higher availability of hedgerows and Walnut trees (Table 4a, Fig. 1). When we added the wider biodiversity index to the set of potential explanatory variables, this was the only variable to enter the model (Table 4b): Scops Owls were associated with higher wider biodiversity than were random sites (Fig. 2).

When comparing the 40 owl territories of the Vallarsa area with the 40 random locations also located within the Vallarsa area, owl territories had higher availability of habitat boundaries and Walnut trees (Table 4c, Fig. 1). Inclusion of the biodiversity index in the set of potential explanatory variables again supported the additional effect of the biodiversity index (Table 4d): within the Vallarsa study area, Scops Owls were associated with higher biodiversity than random sites (Fig. 2). The biodiversity index alone accounted for $60.4 \%$ of the model deviance and a model including the biodiversity index alone correctly reclassified $91.3 \%$ of cases $(90.0 \%$ of the owl territories and $92.5 \%$ of the random locations).

\section{Regional-scale relationships}

With the exception of reptile species, for which the relationship was only marginally significant, all estimates of biodiversity were higher for $10-\mathrm{km}$ grid squares 
Table 2. Environmental variables measured at 40 Scops Owl nests, 40 random locations plotted within an area occupied by the Owl (Vallarsa) and 40 random locations plotted within an area from which the species has virtually disappeared (Italian Alps, 2002-03). Univariate differences between the three samples were tested by means of one-way ANOVA.

\begin{tabular}{|c|c|c|c|c|c|}
\hline Variable & $\begin{array}{l}\text { Scops Owl } \\
\text { territories }\end{array}$ & $\begin{array}{c}\text { Random } \\
\text { (Vallarsa plot) }\end{array}$ & $\begin{array}{l}\text { Random } \\
\text { (Baldo plot) }\end{array}$ & $F_{2,117}$ & $P$ \\
\hline Elevation & $699.6 \pm 24.9$ & $775.8 \pm 37.6$ & $863.0 \pm 27.8$ & 7.1 & 0.0120 \\
\hline Aspect (\% South-oriented)* & 73.9 & 62.6 & 40.0 & $4.9^{\star}$ & 0.430 \\
\hline$\%$ Slope† & $27.3 \pm 1.7$ & $36.3 \pm 2.7$ & $22.0 \pm 1.5$ & 12.5 & 0.002 \\
\hline Ruggedness index $\ddagger$ & $27.4 \pm 1.2$ & $34.3 \pm 2.1$ & $21.4 \pm 0.9$ & 19.7 & 0.076 \\
\hline NND $\ddagger$ & $626.7 \pm 110.3$ & $671.7 \pm 71.8$ & $743.1 \pm 283.1$ & 2.8 & 0.398 \\
\hline Distance to Tawny Owlł & $1399.1 \pm 178.9$ & $1506.6 \pm 173.6$ & $366.2 \pm 29.7$ & 30.8 & 0.004 \\
\hline Distance to grassland & $11.6 \pm 1.9$ & $12.4 \pm 1.5$ & $11.3 \pm 1.8$ & 0.1 & 0.899 \\
\hline Distance to building $†$ & $35.3 \pm 11.7$ & $209.3 \pm 44.8$ & $116.2 \pm 9.3$ & 28.7 & 0.009 \\
\hline$\%$ managed grassland§ & $35.1 \pm 2.3$ & $14.2 \pm 2.0$ & $64.1 \pm 2.5$ & 118.8 & 0.002 \\
\hline$\%$ grassland + shrubs§ & $16.4 \pm 1.9$ & $13.0 \pm 2.2$ & $6.2 \pm 0.9$ & 10.2 & 0.010 \\
\hline$\%$ grassland§ & $51.6 \pm 2.9$ & $27.1 \pm 2.8$ & $70.3 \pm 2.6$ & 59.3 & 0.002 \\
\hline$\%$ intensive farmland§ & $2.6 \pm 1.3$ & $1.5 \pm 0.7$ & $1.1 \pm 0.5$ & 0.4 & 0.700 \\
\hline$\%$ woodland§ & $37.4 \pm 2.9$ & $66.5 \pm 3.3$ & $21.3 \pm 2.1$ & 58.6 & 0.002 \\
\hline$\%$ urban areas§ & $8.1 \pm 1.0$ & $4.5 \pm 1.1$ & $3.9 \pm 1.2$ & 9.7 & 0.002 \\
\hline$\%$ water§ & $0.0 \pm 0.0$ & $0.4 \pm 0.3$ & $0.0 \pm 0.0$ & 2.9 & 0.395 \\
\hline No. of houses $\ddagger$ & $10.1 \pm 1.6$ & $11.0 \pm 1.9$ & $9.2 \pm 1.7$ & 11.2 & 0.008 \\
\hline Habitat richness & $4.7 \pm 0.1$ & $4.3 \pm 0.2$ & $4.7 \pm 0.1$ & 1.8 & 0.523 \\
\hline Habitat diversity $\ddagger$ & $0.29 \pm 0.01$ & $0.36 \pm 0.02$ & $0.39 \pm 0.02$ & 15.8 & 0.010 \\
\hline Interspersion index & $11.9 \pm 0.5$ & $8.2 \pm 0.5$ & $6.9 \pm 0.5$ & 25.5 & 0.009 \\
\hline Grassland interspersion† & $8.2 \pm 0.4$ & $5.6 \pm 0.3$ & $5.4 \pm 0.5$ & 14.3 & 0.006 \\
\hline Hedgerow interspersion $\dagger$ & $15.4 \pm 1.0$ & $8.4 \pm 0.9$ & $8.8 \pm 0.7$ & 19.4 & 0.008 \\
\hline Hedgerows $†$ & $840.3 \pm 78.0$ & $297.7 \pm 40.1$ & $275.1 \pm 31.4$ & 33.3 & 0.006 \\
\hline Field size $\ddagger$ & $3350.3 \pm 442.1$ & $3892.8 \pm 429.1$ & $5056.0 \pm 579.0$ & 4.3 & 0.078 \\
\hline Field perimeter $\dagger$ & $246.4 \pm 14.7$ & $270.9 \pm 14.9$ & $282.1 \pm 14.4$ & 1.9 & 0.608 \\
\hline Perimeter/area $\dagger$ & $0.097 \pm 0.007$ & $0.093 \pm 0.009$ & $0.070 \pm 0.003$ & 5.4 & 0.054 \\
\hline Walnut trees & $5.0 \pm 0.5$ & $1.2 \pm 0.3$ & $1.1 \pm 0.3$ & 32.9 & 0.007 \\
\hline Stone walls & $29.0 \pm 4.1$ & $23.1 \pm 4.4$ & $9.3 \pm 2.3$ & 6.8 & 0.016 \\
\hline Mowing frequency & 100.0 & 100.0 & 0.0 & 152.79 & 0.002 \\
\hline Biodiversity index & $1.05 \pm 0.07$ & $-0.24 \pm 0.11$ & $-0.81 \pm 0.12$ & 90.3 & 0.002 \\
\hline
\end{tabular}

*\% South-oriented, tested by means of a Chi-squared test on count data.

†ANOVA conducted on the variable square root transformed.

ҒANOVA conducted on the variable $\log _{\mathrm{e}}$ transformed.

§ANOVA conducted on the variable transformed in the arcsin square root of the proportion.

I\% mown once a year, tested by means of a Chi-squared test on count data.

Table 3. Effect of environmental variables on biodiversity in two study areas of the Italian Alps (2002-3).

\begin{tabular}{lccc}
\hline Variable & $\begin{array}{c}\text { Parameter } \\
\text { estimate } \pm \text { se }\end{array}$ & $t$ & $\begin{array}{c}\text { \% deviance } \\
\text { explained }\end{array}$ \\
\hline Dependent variable: biodiversity index $(\boldsymbol{n}=\mathbf{1 2 0})^{\star} \dagger$ & & & \\
$\quad$ Habitat richness & $0.30 \pm 0.06$ & 4.99 & $<0.0002$ \\
$\quad$ Hedgerow length $\ddagger$ & $0.03 \pm 0.01$ & 5.12 & $<0.0003$ \\
$\quad$ No. of Walnut trees & $0.10 \pm 0.02$ & 5.07 & $<0.0004$ \\
$\quad$ Mowing frequency§ & $-0.87 \pm 0.12$ & 7.08 & $<0.00001$ \\
$\quad$ Constant & $-1.98 \pm 0.29$ & - & - \\
\hline
\end{tabular}

*Calculated as the first component in a PCA conducted on various biodiversity estimates (see Methods).

TGLM linear regression with normal errors and an identity link function (Crawley 1993).

$\ddagger$ Variable square root transformed.

§Categorical, dichotomous variable. 

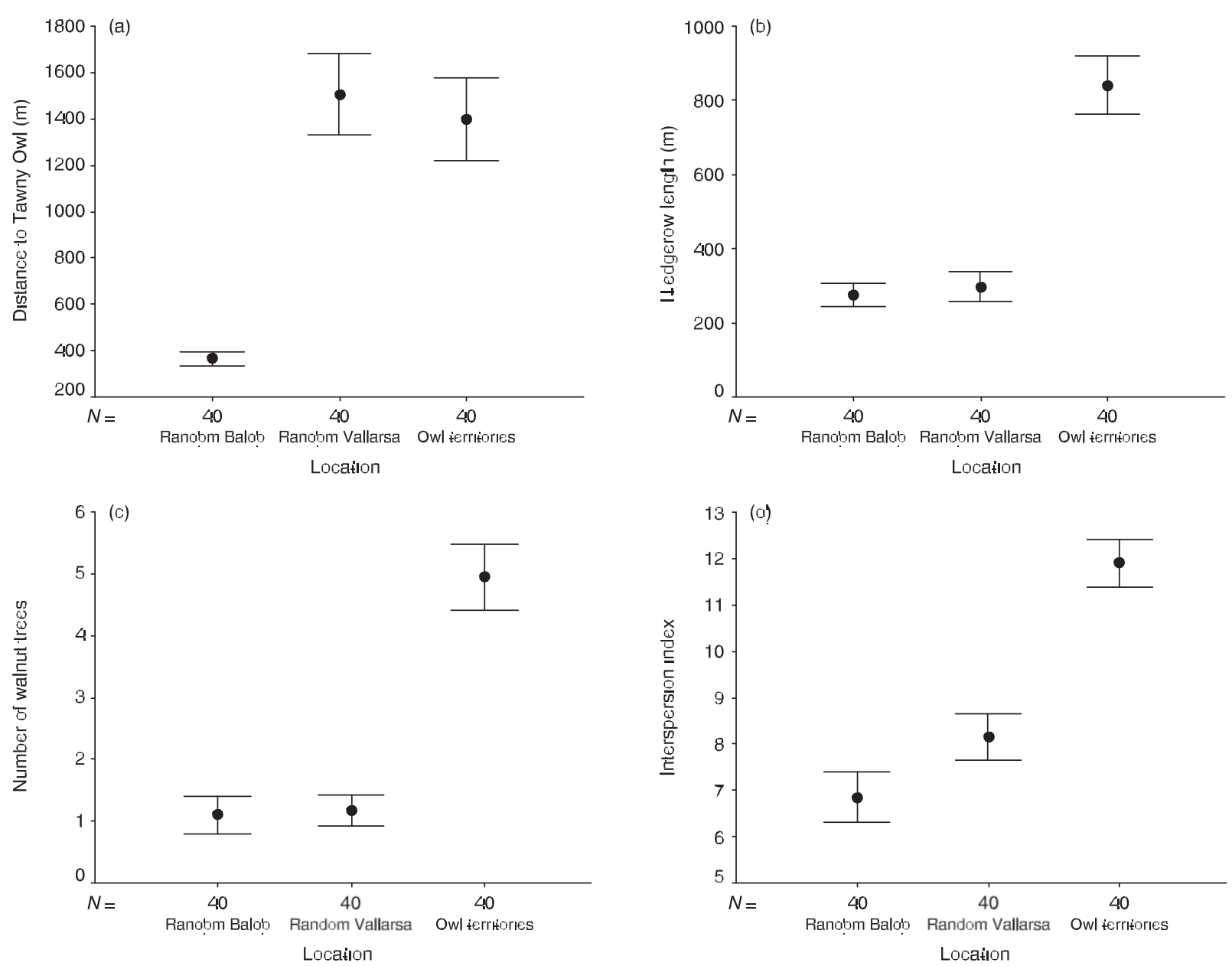

Figure 1. Mean ( $\pm 1 \mathrm{se}$ ) distance to the nearest Tawny Owl territory, availability of hedgerows, Walnut trees and abundance of habitat boundaries for 40 sites occupied by Scops Owls for breeding, 40 locations randomly chosen within a macro-area used by Scops Owls for breeding (Vallarsa) and 40 sites randomly chosen within an area from which Scops Owls are virtually extinct (Baldo).

occupied by Scops Owls than for unoccupied squares (Table 5); all differences were in the expected direction (binomial test, $P=0.031$ ). Furthermore, the density of Scops Owl territories in the 21 occupied squares was positively related to the richness of amphibian species $\left(r_{s}=0.58, P=0.030\right)$, of bird species $\left(r_{s}=0.50\right.$, $P=0.044)$, of bird species in category SPEC $1+2+$ $3+4\left(r_{s}=0.54, P=0.036\right)$, in category SPEC $1+2+3$ $\left(r_{s}=0.55, P=0.036\right)$, and of the cumulated species of amphibians + reptiles + birds $\left(r_{s}=0.62, P=0.018\right)$.

\section{DISCUSSION}

Spatial variation in Scops Owl distribution and abundance reflected the gradient of intensification of agricultural practices. This is consistent with the hypothesis that Scops Owl declines have been driven by agricultural change (Arlettaz 1990, Arlettaz et al. 1991, Bavoux et al. 1997), a continentwide process that has caused enormous reductions in European bird populations (e.g. Pain \& Pienkowski 1997, Tucker \& Evans 1997). In particular, when random locations were plotted in an area where the species is almost extinct (Baldo plot), Scops Owls territories differed from random locations in terms of: (1) two indicators of extensive agriculture (hedgerows and isolated trees) and (2) proximity to a potential predator, the Tawny Owl. Extensive farmland rich in hedgerows and isolated, large trees may benefit the owls by providing hunting perches, nesting cavities and a diversified landscape rich in prey, and by favouring, through such extensive management, grassland fields with high and wellspaced apart grass-swards, high plant diversity, and 


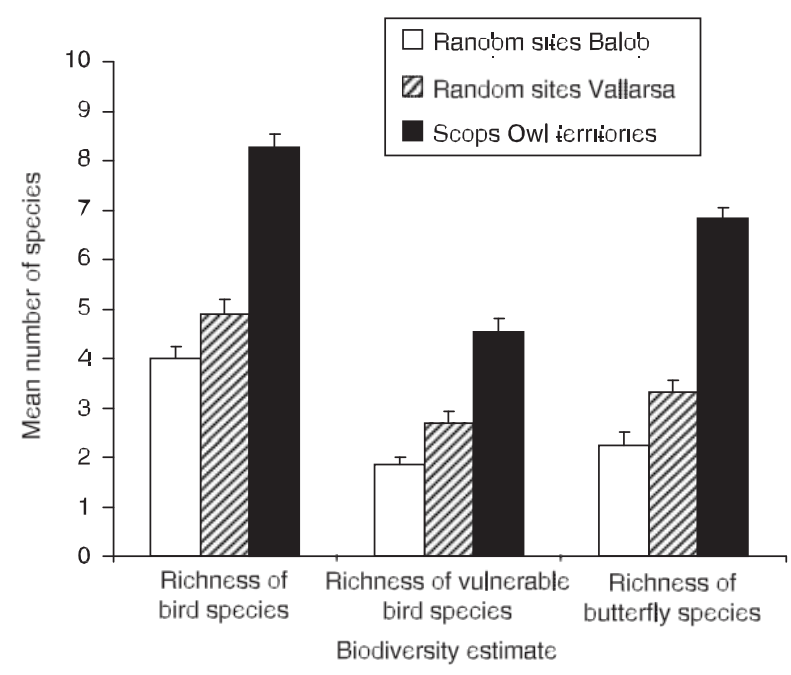

Figure 2. Richness of bird species, vulnerable bird species and butterfly species is maximum at 40 sites occupied by Scops Owls for breeding, intermediate at 40 locations randomly chosen within a macro-area used by Scops Owls for breeding (Vallarsa) and minimum at 40 sites randomly chosen within an area from which Scops Owls are virtually extinct (Baldo).

with an abundant and well-diversified entomofauna, especially rich in grasshoppers, the main prey (e.g. Andrews \& Rebane 1994, Glem et al. 1995, Gottschalk et al. 2003). The fact that indicators of extensively managed, mosaic farmland also discriminated between micro-sites occupied or not by Scops Owl within an area (Vallarsa) where the species is still abundant reinforces the sensitivity of this species to the degree of intensification of agricultural practices. Similar dependence on heterogeneous landscapes rich in habitat edges has been reported in a recent study from southern Spain, where increasing urbanization was identified as an additional threat for the species (Martínez et al. 2007).

The apparent avoidance of a potential predator accords with an increasing consensus about the potential limitation of raptor populations through intraguild predation and the need to take into account such interspecific relationships within raptor habitat selection models, especially for small-sized species such as the Scops Owl (Hakkarainen \& Korpimäki 1996, Petty et al. 2003, Sergio et al. 2003, 2007,Gutiérrez et al. 2007, Sergio \& Hiraldo 2008). Two observations further confirm the idea that Tawny Owls may limit the distribution of Scops Owls. On two separate occasions, while surveying Scops Owls through conspecific playback stimulation, observers were silently approached by Tawny Owls that perched very near and looked intently in the direction of the speaker.
We believe that these were ambush attempts of individuals responding to the Scops Owls' territorial calls. Given the very secretive behaviour of the two observed Tawny Owls, we suspect that such events could have happened more frequently but gone undetected. Also, intensive sampling of Tawny Owl diet in the Baldo area led to the detection of remains of a Scops Owl within a Tawny Owl pellet (Marchesi et al. 2006). The only Scops Owl territory known in the Baldo area in such a period disappeared at the time of this predation episode, suggesting that predation may limit local settlement by Scops Owls. These casual observations support the idea that Tawny Owls may have contributed to drive the local decline of Scops Owl or to limit their recolonization of the Baldo area. The fact that Tawny Owl density was higher in the Baldo plot than in the Vallarsa area is also suggestive of a threshold of abundance, beyond which the effect of Tawny Owl predation risk on Scops Owl occurrence becomes evident (Sergio et al. 2007). For example, the density and distribution of Tawny Owls in the Vallarsa area allowed Scops Owls to occupy sites that were on average $1.4 \mathrm{~km}$ from the nearest Tawny Owl (Fig. 1a), probably far enough to allow long-term coexistence.

Scops Owls were increasingly less likely to occur along a spatial gradient of agricultural intensification, which reproduced the temporal trend of change in farming practices that started in the first half of the 20th century and accelerated exponentially in the past 50 years throughout Europe (Mannion 1995). The observed patterns of change along this gradient, and their biodiversity implications, would have been even steeper had we also sampled farmland plots in the valley floors, where agricultural intensification is at its highest, biodiversity at its minimum regional values (unpubl. data) and from which Scops Owls disappeared many decades ago.

The most consistent result across all comparisons, gradients and spatial scales was the tight link between the occurrence of Scops Owls and indices of wider biodiversity. Such indices were capable of predicting Scops Owl occurrence with high accuracy (91-96\% correctly reclassified cases). In turn, both Scops Owl occurrence and indices of biodiversity depended on a set of indicators of agricultural intensification, suggesting that the observed association was promoted by a common response to the same underlying factor: agricultural management. Such results confirmed an earlier analysis based on a smaller sample (Sergio et al. 2005a, 2006a). It would be interesting to test whether similar associations 
Table 4. Effect of environmental variables on Scops Owl occurrence in the Italian Alps (2002-3).

\begin{tabular}{|c|c|c|c|c|c|}
\hline Variable & $\begin{array}{l}\text { Parameter } \\
\text { estimate } \pm \text { se }\end{array}$ & $t$ & $P$ & $\begin{array}{l}\% \text { deviance } \\
\text { explained }\end{array}$ & $\begin{array}{c}\% \text { correctly } \\
\text { reclassified cases } \\
(\% \text { owls; } \% \text { random })^{\star}\end{array}$ \\
\hline $\begin{array}{l}\text { a. Response: Scops Owl presence-absence } \\
\text { (Owls Vallarsa vs. random Baldo, } n=80) \dagger\end{array}$ & & & & 71.4 & $95.0(92.5 ; 97.5)$ \\
\hline Hedgerow length & $0.19 \pm 0.06$ & 2.98 & $<0.01$ & & \\
\hline Walnut trees & $0.49 \pm 0.16$ & 2.95 & $<0.02$ & & \\
\hline Distance to Tawny Owl & $2.71 \pm 0.77$ & 3.51 & $<0.001$ & & \\
\hline Constant & $-22.50 \pm 5.59$ & - & - & & \\
\hline $\begin{array}{l}\text { b. Response: Scops Owl presence-absence, biodiversity } \\
\text { included (Owls Vallarsa vs. random Baldo, } n=80) \ddagger\end{array}$ & & & & 81.5 & $96.3(97.5 ; 95.0)$ \\
\hline Biodiversity index§ & $6.11 \pm 1.05$ & 5.84 & $<0.0002$ & & \\
\hline Constant & $-2.09 \pm 0.59$ & - & - & & \\
\hline $\begin{array}{l}\text { c. Response: Scops Owl presence-absence } \\
\text { (Owls Vallarsa vs. random Vallarsa, } n=80) \uparrow\end{array}$ & & & & 44.8 & $80.0(80.0 ; 80.0)$ \\
\hline Interspersion index & $0.37 \pm 0.11$ & 3.40 & $<0.002$ & & \\
\hline Walnut trees & $0.63 \pm 0.17$ & 3.78 & $<0.003$ & & \\
\hline Constant & $-5.28 \pm 1.29$ & - & - & & \\
\hline $\begin{array}{l}\text { d. Response: Scops Owl presence-absence, biodiversity } \\
\text { included (Owls Vallarsa vs. random-Vallarsa, } n=80)^{\star \star}\end{array}$ & & & & 74.8 & $93.8(95.0 ; 92.5)$ \\
\hline Interspersion index & $0.55 \pm 0.18$ & 3.01 & $<0.010$ & & \\
\hline Walnut trees & $0.48 \pm 0.20$ & 2.41 & $<0.020$ & & \\
\hline Biodiversity index & $4.84 \pm 1.05$ & 4.61 & $<0.0003$ & & \\
\hline Constant & $-9.50 \pm 2.59$ & - & - & & \\
\hline
\end{tabular}

*Percentage correctly reclassified cases when the model is re-applied to the data. In parentheses are shown: the percentage of Owl territories correctly reclassified by the model and the percentage of random locations correctly re-classified by the model.

TGLM logistic regression with binomial errors and a logit link function (Crawley 1993) discriminating between 40 Owl territories and 40 locations randomly plotted in the Baldo study plot. Variables presented to the model: elevation, \% slope, Distance to Tawny Owl, \% grassland, \% grassland + shrubs, \% woodland, \% urban areas, interspersion index, hedgerow interspersion, hedgerows, Walnut trees, No. of houses, stone walls, mowing frequency, perimeter/area, and interaction term between \% woodland * Walnut trees.

$\ddagger$ Same model as above, but with the inclusion of the biodiversity index within the set of explanatory variables.

$\S$ Calculated as the first component in a PCA conducted on various biodiversity estimates (see Methods).

ॠGLM logistic regression with binomial errors and a logit link function (Crawley 1993) discriminating between 40 Owl territories and 40 locations randomly plotted in the Vallarsa study plot. Variables presented to the model: \% slope, \% managed grassland, \% grassland, $\%$ grassland + shrubs, \% woodland, \% urban areas, habitat diversity, interspersion index, hedgerow interspersion, hedgerows, Walnut trees, No. of houses, and interaction term between \% woodland * Walnut trees.

**Same model as above, but with the inclusion of the biodiversity index within the set of explanatory variables.

Table 5. Richness of vertebrate species in 21 quadrats of $10 \times 10 \mathrm{~km}$ occupied by Scops Owls and 21 quadrats randomly selected within the Trento region of the Italian Alps.

\begin{tabular}{|c|c|c|c|c|}
\hline Variable & $\begin{array}{l}\text { Quadrats occupied } \\
\text { by Scops Owls }\end{array}$ & $\begin{array}{l}\text { Random } \\
\text { quadrats }\end{array}$ & $t_{40}$ & $P$ \\
\hline Richness of bird species & $99.38 \pm 2.84$ & $74.90 \pm 4.37$ & -4.70 & 0.0009 \\
\hline Richness of bird species (SPEC $1+2+3+4)$ & $49.10 \pm 1.61$ & $33.19 \pm 2.59$ & -5.21 & 0.0005 \\
\hline Richness of bird species (SPEC $1+2+3)^{\star}$ & $23.95 \pm 0.86$ & $13.29 \pm 1.33$ & -6.57 & 0.0012 \\
\hline Richness of amphibian species $\dagger$ & $5.95 \pm 0.45$ & $3.90 \pm 0.34$ & -3.45 & 0.0040 \\
\hline Richness of reptile species & $7.90 \pm 0.28$ & $6.71 \pm 0.61$ & -1.79 & 0.0830 \\
\hline Richness of vertebrate species & $104.76 \pm 3.28$ & $80.05 \pm 4.48$ & -4.45 & 0.0003 \\
\hline
\end{tabular}

${ }^{*} t$-test carried out on the variable square root transformed.

$t t$-test carried out on the variable $\log _{\mathrm{e}}$ transformed. 
with biodiversity-rich sites occur in other habitats or portions of this species' distribution.

The persistence of Alpine Scops Owl populations might be best accomplished through subsidy schemes capable of halting the rapid scrub encroachment caused by land abandonment, which would ultimately lead to widespread loss of the grassland habitats favoured by the species, and reducing the degree of intensification of local grassland management. The most rapid and simple way to promote the persistence of current populations would be to focus on the currently occupied sites and their surroundings and favour a low mowing frequency at such sites, ideally with one grassland harvest per year. In areas where the intensification of grassland management is already pronounced and where the species has recently disappeared, subsidies could be established to promote planting of hedgerows and scattered trees as a long-term strategy. Further interventions could involve setting-aside some of the fields in each area to be managed less intensively, or creating grassland strips, 10-20 m wide and mowed every other year, along the borders of existing fields, as recently attempted in the Swiss Alps (R. Arlettaz pers. comm.). Finally, in areas where scrub encroachment has already removed whole grassland patches, subsidies could be established to restore grassland through scrub removal and subsequent low intensity management. In our study region, this type of restoration has been already accomplished, but at higher elevations and by targeting game species (Odasso et al. 2002). All proposed interventions would not exclusively favour Scops Owls but also a suite of other conservationsensitive species known to be strongly affected by the current rapid loss of open grassland habitats (Laiolo et al. 2004, Sergio et al. 2006b). Furthermore, such subsidies are expected to yield broader community effects because they were designed on the basis of a species which over-selects biodiversityrich sites, and the managed components of the proposed subsidies are the factors themselves that promote the tight association between Scops Owls and biodiversity.

Our results confirm the importance of a landscape and ecosystem approach to the management of vertebrate predators (e.g. Noss et al. 1996, Gittleman et al. 2001, Sergio et al. 2003). The populations of such species are unlikely to be preserved by conservation strategies that do not take into account the whole ecosystem on which such species depend, and that provide only solutions for limited components of these species' requirements (e.g. provision of nest boxes). In the Alps, the preservation and recovery of Scops Owl populations seem tightly dependent on the restoration of the traditional, extensive way to manage their grassland ecosystem, which is probably best achieved through subsidy schemes.

We thank R. Arlettaz, J. F. Calvo, P. F. Donald, M. Licantropi, J. Quinn and an anonymous reviewer for comments on a first draft of the manuscript. This study was included in 'Project Biodiversità', funded by the Autonomous Province of Trento.

\section{REFERENCES}

Andrews, J. \& Rebane, M. 1994. Farming and Wildlife: A Practical Management Handbook. Sandy, UK: RSPB.

Arlettaz, A. 1990. La population relictuelle de Hibou Petit-duc, Otus scops, en Valis central: dynamique, organisation spatiale, habitat et protection. Nos Oiseaux 40: 321-343.

Arlettaz, R., Fournier, J., Juillard, M., Lugon, A., Rossel, D. \& Sierro, A. 1991. Origines du déclin de la population relictuelle de Hibou Petit-duc, Otus scops, dans les Alpes valaisannes (sud-ouest de la Suisse): une approche empirique. In Juillard, M., Bassin, P., Baudven, H., Génot, P., Ravussin, P. \& Rebetez, C. (eds) Rapaces Nocturnes: 15-30. Prangins, Switzerland: Société romande pour l'étude et la protection des oiseaux.

Barbaro, L., Dutoit, T. \& Cozic, P. 2001. A 6-year experimental restoration of biodiversity by shrub-clearing and grazing in calcareous grasslands of the French Alps. Biodiv. Conserv. 10: $119-135$.

Bavoux, C., Burneleau, G. \& Nicolau-Guillaumet, P. 1997. Scops Owl Otus scops. In Hagemeijer, W.J.M. \& Blair, M.J. (eds) The EBCC Atlas of European Breeding Birds, Their Distribution and Abundance: 400-401. London: T. \& A.D. Poyser.

Bonomi, A. 1884. Avifauna Tridentina. Rovereto: Museo Civico di Rovereto.

Brouer, F. \& Crabtree, B. (eds) 1999. Environmental Indicators and Agricultural Policy. Oxford: CABI Publishing.

Burfield, I. \& van Bommel, F. 2004. Birds in Europe: Population Estimates, Trends and Conservation Status. Cambridge, UK: BirdLife International.

Canals, R. \& Sebastià, M. 2000. Analyzing mechanisms regulating diversity in rangelands through comparative studies: a case in the southwestern Pyrenees. Biodiv. Conserv. 9: 965-984.

Cernusca, A., Tappeiner, U. \& Bayfield, N. 1999. Land-use changes in European mountain ecosystems. Blackwell Wissenschafts-Verlag, Berlin.

Chemini, C. 1993. Butterflies of the Trento Region. Trento: Edizioni Novecento.

CIPRA (International Commission for the Protection of the Alps). 2001. Report on the State of the Alps 2: Data, Facts, Problems, Proposals. Turin: Centro Documentazione Alpina.

Cramp, S. (ed.) 1985. The Birds of the Western Palearctic, Vol. 4. Oxford: Oxford University Press.

Crawley, M.J. 1993. GLIM for Ecologists. Oxford: Blackwell Science.

Dirnböck, T., Dullinger, S. \& Grabherr, G. 2003. A regional impact assessment of climate and land-use change on alpine vegetation. J. Biogeog. 30: 401-407. 
Fusco, N. (ed.) 2002. Mountains of Italy. Milan: Istituto Geografico De Agostani.

Galeotti, P. \& Gariboldi, A. 1994. Territorial behaviour and habitat selection by the Scops Owl Otus scops in a Karstic Valley (NE Italy). In Meyburg, B.U. \& Chancellor, R.D. (eds) Raptor Conservation Today: 501-505. East Sussex, UK: WWGBP \& Pica Press.

Galeotti, P. \& Sacchi, R. 2001. Turnover of territorial Scops Owls Otus scops as estimated by spectrographic analyses of male hoots. J. Avian Biol. 32: 256-262.

Gaston, K.J. (ed.) 1996. Biodiversity: A Biology of Numbers and Difference. Oxford: Blackwell Science.

Gittleman, J.L., Funk, S.M., Macdonald, D.W. \& Wayne, R.K. (eds) 2001. Carnivore Conservation. Cambridge: Cambridge University Press.

Glem, D.H., Greaves, M.P. \& Anderson, H.M. (eds) 1995. Ecology of Integrated Farming Systems. Chichester: John Wiley \& Sons.

Gottschalk, E., Griebeler, E.M., Waltert, M. \& Mühlenberg, M. 2003. Population dynamics in the Grey Bush Cricket Platycleis albopunctata (Orthoptera: Tettigoniidae) - what causes interpopulation differences? J. Insect Conserv. 7: 45-58.

Green, R.H. 1979. Sampling Design and Statistical Methods for Environmental Biologists. New York: John Wiley \& Sons.

Gutiérrez, R.J., Cody, M., Courtney, S. \& Franklin, A.B. 2007. The invasion of Barred Owls and its potential effect on the Spotted Owl: a conservation conundrum. Biol. Invasions 9: 181-196.

Hakkarainen, H. \& Korpimäki, E. 1996. Competitive and predatory interactions among raptors: an observational and experimental study. Ecology 77: 1134-1142.

Hooge, P.N. \& Eichenlaub, B. 1997. Movement. Animal Movement Extension to ArcView ver. 1.1. Anchorage: Alaska Biological Science Center, US Geological Survey.

ICBP (International Council for Bird Preservation). 1987. The Value of Birds. Cambridge, UK: ICBP.

ICBP (International Council for Bird Preservation). 1992. Putting Biodiversity on the Map: Priority Areas for Global Conservation. Cambridge, UK: ICBP.

Kerr, J.T., Sugar, A. \& Packer, L. 2000. Indicator taxa, rapid biodiversity assessment, and nestedness in an endangered ecosystem. Cons. Biol. 14: 1726-1734.

Krebs, C.J. 1998. Ecological Methodology. New York: HarperCollins.

Laiolo, P., Dondero, F., Ciliento, E. \& Rolando, A. 2004. Consequences of pastoral abandonment for the structure and diversity of the alpine avifauna. J. Appl. Ecol. 41: 294-304.

Lichtenbergen, E. 1994. Die Alpen in Europa. Veröff. Komm. Humanökol. 5: 53-86.

Mannion, A.M. 1995. Agriculture and Environmental Change: Temporal and Spatial Dimensions. Chichester: John Wiley \& Sons.

Marchesi, L. \& Sergio, F. 2005. Distribution, density, diet and productivity of the Scops Owl Otus scops in the Italian Alps. Ibis 147: 176-187.

Marchesi, L., Sergio, F. \& Pedrini, P. 2006. Implications of temporal changes in forest dynamics on density, nest-site selection, diet and productivity of the Tawny Owl Strix aluco in the Alps: implications of temporal changes in forest dynamics. Bird Study 53: 310-318.

Martínez, J.A., Zuberogoitia, I., Martínez, J.E., Zabala, J. \& Calvo, J.F. 2007. Patterns of territory settlement by Eurasian Scops-owls (Otus scops) in altered semi-arid landscapes. J. Arid Environ. 69: 400-409.

Mikkola, H. 1983. Owls of Europe. Calton: T. \& A.D. Poyser.
Niemelä, J. \& Baur, B. 1998. Threatened species in a vanishing habitat: plants and invertebrates in calcareous grasslands in the Swiss Jura Mountains. Biodiv. Conserv. 7: 1407-1416.

Noss, R.F., Quigley, H.B., Hornocker, M.G., Merrill, T. \& Paquet, P.C. 1996. Conservation biology and carnivore conservation in the Rocky Mountains. Conserv. Biol. 10: 949-963.

Odasso, M., Mayr, S., De Franceschi, P.F., Zorzi, S. \& Mattedi, S. 2002. Miglioramenti Ambientali a Fini Faunistici: Localizzazione Delle Zone, Priorità e Modalità Gestionali per Interventi a Favore di Lepre Comune, Fagiano di Monte, Coturnice e Re di Quaglie. Trento: Provincia Autonoma di Trento.

Pain, D.J. \& Pienkowski, M.W. (eds) 1997. Farming and Birds in Europe: The Common Agricultural Policy and its Implications for Bird Conservation. London: Academic Press.

Pedrini, P. \& Sergio, F. 2002. Regional conservation priorities for a large predator: Golden Eagles (Aquila chrysaetos) in the Alpine range. Biol. Conserv. 103: 163-172.

Petty, S.J., Anderson, D.I.K., Davison, M., Little, B., Sherratt, T.N., Thomas, C.J. \& Lambin, X. 2003. The decline of Common Kestrels Falco tinnunculus in a forested area of northern England: the role of predation by Northern Goshawks Accipiter gentilis. Ibis 145: 472-483.

Purvis, A. \& Hector, A. 2000. Getting the measure of biodiversity. Nature 405: 212-219.

Sergio, F. \& Hiraldo, F. 2008. Intraguild predation in raptor assemblages: a review. Ibis, in press.

Sergio, F. \& Pedrini, P. 2007. Biodiversity gradients in the Alps: the overriding importance of elevation. Biodiv. Conserv. 16: 3243-3254.

Sergio, F., Marchesi, L. \& Pedrini, P. 2003. Spatial refugia and the coexistence of a diurnal raptor with its intraguild owl predator. J. Anim. Ecol. 72: 232-245.

Sergio, F., Newton, I. \& Marchesi, L. 2005a. Top predators and biodiversity. Nature 436: 192.

Sergio, F., Scandolara, C., Marchesi, L., Pedrini, P. \& Penteriani, V. 2005b. Effect of agro-forestry and landscape changes on Common Buzzards (Buteo buteo) in the Alps: implications for conservation. Anim. Conserv. 7: 17-25.

Sergio, F., Newton, I., Marchesi, L. \& Pedrini, P. 2006a. Ecologically justified charisma: preservation of top predators delivers biodiversity conservation. J. Appl. Ecol. 43: 1049-1055.

Sergio, F., Pedrini, P., Rizzolli, F. \& Marchesi, L. 2006b. Adaptive range selection by Golden Eagles in a changing landscape: a multiple modelling approach. Biol. Conserv. 133: 32-41.

Sergio, F., Marchesi, P., Pedrini, P. \& Penteriani, V. 2007. Coexistence of a generalist owl with its intraguild predator: distance-sensitive or habitat-mediated avoidance? Anim. Behav. 74: 1607-1616.

Sokal, R.R. \& Rohlf, F.J. 1981. Biometry. New York: W. H. Freeman.

Tabachnick, B.G. \& Fidell, L.S. 1996. Using Multivariate Statistics. New York: HarperCollins.

Tolman, T. 1997. Collins Field Guide to Butterflies of Britain and Europe. London: HarperCollins.

Tucker, G.M. \& Evans, M.I. 1997. Habitats for Birds in Europe: A Conservation Strategy for the Wider Environment. Cambridge, UK: BirdLife International.

Tucker, G.M. \& Heath, M.F. 1994. Birds in Europe: Their Conservation Status. Cambridge, UK: BirdLife International.

Received 30 October 2007; revision accepted 19 June 2008. 